\title{
Possible Use of Treated Wastewater as Irrigation Water at Urban Green Area
}

\author{
Elif Bozdogan ${ }^{1 *}$ \\ ${ }^{1 *}$ Department of Landscape Architecture, Faculty of Agriculture, Mustafa Kemal University, 31040 Antakya/Hatay, Turkey
}

\section{A R T I C LE IN F O}

Article history:

Received 04 June 2014

Accepted 13 August 2014

Available online, ISSN: 2148-127X

\section{Keywords:}

Reuse

Treated Wastewater

Irrigation

Urban Green Area

Marigold

"Corresponding Author:

E-mail: ebozdogan@mku.edu.tr

\section{A B S T R A C T}

Ever increasing demands for fresh water resources have brought the reuse of treated wastewater into agendas. Wastewater has year-long potential to be used as an irrigation water source. Therefore, treated wastewater is used as irrigation water over agricultural lands and urban landscapes, as process water in industrial applications, as back-up water in environmental applications in water resources and wetlands of dry regions. The present study was conducted to investigate the possible use of domestic wastewater treated through pilot-scale constructed wetland of Adana-Karaisalı with dominant Mediterranean climate in irrigation of marigold (Tagetes erecta), commonly used over urban landscapes. Experiments were carried out between the dates May-November 2008 for 7 months with fresh water and treated wastewater. Plant growth parameters (plant height, plant diameter, number of branches) and flowering parameters (number of flowers, flower diameter, flower pedicle thickness) were monitored in monthly basis. Results revealed positive impacts of treated wastewater irrigations on plant growth during the initial 5 months between May-September but negative impacts in October and November. Similarly, treated wastewater irrigations had positive impacts on flowering parameters during the initial 3 months but had negative impacts during the subsequent 4 months. Such a case indicated shortened visual efficiencies of marigold. Therefore, treated wastewater can be used as an alternative water resource in irrigation of annual flowers, but better results can be attained by mixing treated wastewater with fresh water at certain ratios.

\section{Introduction}

Increasing world population, industrial and technological developments also increased both the use and demands for fresh water resources. It is estimated that about $2 / 3$ of world population will experience a water deficiency at medium or high level by the year 2025 (EPA, 2004). World total water resources is 1.4 billion $\mathrm{m}^{3}$ (DSI, 2012) and only $1 \%$ of this amount is used as potable water (Cassaniti et al., 2013). Total surface and groundwater resources of Turkey are 112 million $\mathrm{m}^{3}$ and about $40 \%$ of this amount is actively used today. Annual amount of water per capita is $1519 \mathrm{~m}^{3}$ in Turkey and with this amount Turkey is classified among the countries experiencing a water deficiency (DSİ, 2012).

Since almost half of the world population lives in urban sections (EC, 2012), both the demand for fresh water resources and the amount of wastewater are increasing every day. Such a case have brought the reuse of wastewater to support the fresh water resources into urban agendas (Brenner et al. 2000; Lubello et al., 2004; Grieve et al., 2006; Niu and Cabrera, 2010; Chang and Ma, 2012; Paulo et al., 2013). Reuse of wastewater through treating with various methods is a significant issue in efficient and sustainable use of water resources. Wastewater has year-long potential to provide solutions for water deficiency, to allow high quality waters to be used as potable water and to provide several economic benefits (Levine and Asano, 2004; Lubello et al., 2004; Grieve et al., 2006; Meneses et al., 2010). Wastewater is treated with several methods such as biological treatment, mechanical aerated lagoons, stabilization ponds, constructed wetlands and etc. (Balman and Balman, 2002). As distinct from the other treatment methods, $99 \%$ microbiological treatment is achieved in constructed wetland systems. Therefore, these systems are highly significant in reuse of wastewater (Bozdoğan, 2009).

Treated wastewater is reused especially in agricultural lands, urban, industrial, environmental and recreational sites and used also to support groundwater sources. In urban sections, treated wastewater is used as an alternative water resource in irrigation of parks and recreation sites, sports sites, school gardens, road sides and refuges (EPA, 2004). Worldwide, treated wastewater is mostly used in agricultural irrigations and reuse in other sites directed by the own needs of the countries (Braatz and Kandiah, 2005; EPA, 2004; IRC, 2005; Shetty, 2005; Grieve et al., 2006; Bakopoulou et al., 2011). For instance, treated wastewaters are used to enrich river flows and poplar growth in Spain (Braatz and Kandiah, 2005; Lazarova, 1999). Again in Spain-Barcelona, treated wastewaters are used as an alternative water resource to 
overcome the water shortage problems experienced in summer months and to support river flows (Cazurra, 2008). Wastewater is designated as a valuable resource to be managed sustainable in Greece (Andreadakis et al., 2001). Wastewater reuse is mostly emphasized in some states of the United States of America. They emphasized treated wastewater use in open landscapes, agricultural lands, recreation sites, industrial and natural sites (habitat restoration, support natural wetlands) (FDEP, 2002; SFWMD, 2002; EPA, 2004). However, usages of treated wastewater should be monitored for years since they may have toxic impacts on plants, some elements (heavy metals) may accumulate in soils, and wastewater may be involved in groundwater (Qian, 2006; Bakopoulou et al., 2011; Oliveira-Marinho et al., 2013). Cost of treated wastewater (Hochstrat et al., 2007), quality, acceptability by the users, support by local administrations are among the other factors effecting the reuse of treated wastewaters (Chang and Ma, 2012). Despite the effects of all these factors, together with decreasing water resources, scientific researches and implementations on reuse of treated wastewater is increasing every day (Bozdoğan et al., 2010).

In landscape architecture profession, treated wastewater usage is mostly observed in irrigation of landscape plants and researches are usually implemented in landscape irrigation. Irrigation of design plants with treated wastewaters was investigated in woody plants (Gori et al., 2000; Sakellariou-Makrantonaki et al., 2003; Lubello et al., 2004; Gerhart et al., 2006; Banon et al., 2011; Oliveira-Marinho et al., 2013), herbaceous-annual plants (Carter et al., 2005; Grieve et al., 2006; Carter and Grieve, 2008; Bizhani et al., 2013; Cassaniti et al., 2013) and herbaceous-perennial plants and grasses (Gerhart et al., 2006; Qian, 2006; Bozdoğan, 2009; Bozdoğan et al., 2010; Bozdoğan, 2013).

\section{Temperature $\left({ }^{\circ} \mathrm{C}\right)$}

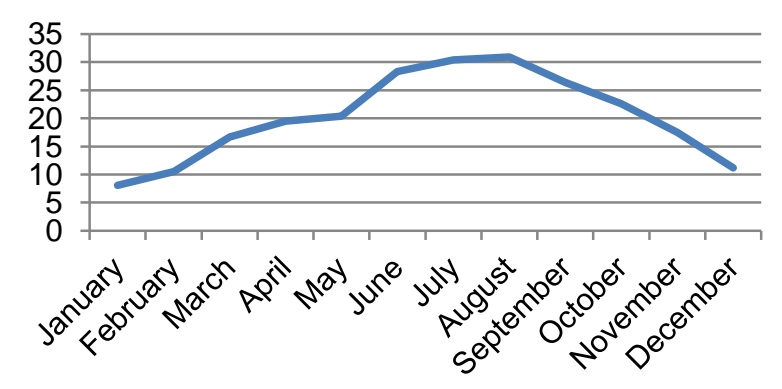

Total precipitation $(\mathrm{mm})$

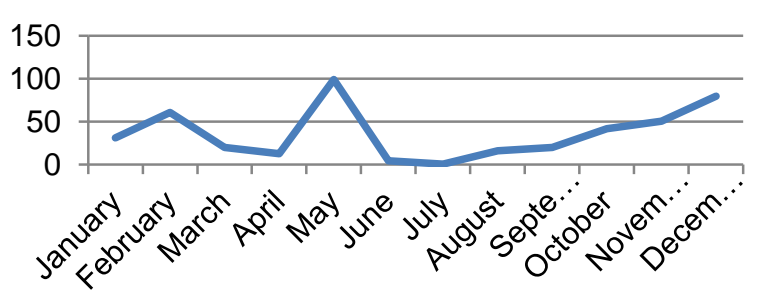

The present study was conducted to put forward the possible use of treated wastewater in open and green landscapes to provide a support for sustainability of water resources. The results obtained from marigold (T.erecta) irrigation in Adana-Karaisalı may contribute a sample case for other annual landscape plants used in urban landscapes of other Mediterranean cities.

\section{Material and Method}

The present research was conducted in Karaisalı Town of Adana, Turkey between the dates May and November 2008 for 7 months.

Karaisal 1 is $50 \mathrm{~km}$ from Adana and it is located within Mediterranean climate zone. The climate data [temperature $\left({ }^{\circ} \mathrm{C}\right)$, relative humidity $(\%)$, total precipitation $(\mathrm{mm})$, number of rainy days (day)] for the research year are presented in Figure 1 (Bozdoğan, 2009).

Marigold (Tagetes erecta) was selected as the plant material of the study to investigate the possible use of treated wastewater as irrigation water. Marigold has a significant visual efficiency and is able to enrich air quality. Therefore, it is commonly used in landscape architectural implementations of urban area. T. erecta is a member of Asteraceae (composite flowers) family and it is native to Mexico. It is used seasonally in flower beds, balconies and terraces. It has intensive branching and can reach to a height of $100 \mathrm{~cm}$. The scented leaves are multipartly structure and opposite arranging; the margins of the serrat leaflets are oblong-lanceolate (Ebcioğlu, 2009; Yücel, 2012). The flowers sized 5-10 $\mathrm{cm}$ have yellow and orange colors. The blooming time is the summer and autumn seasons (Yücel, 2012). There may be one or more scented flowers over a long stem (Orçun, 1972).

\section{Relative humidity (\%)}

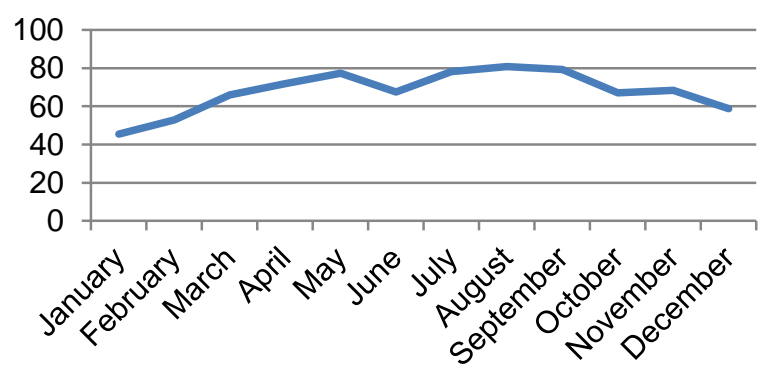

Number of rainy days (day)

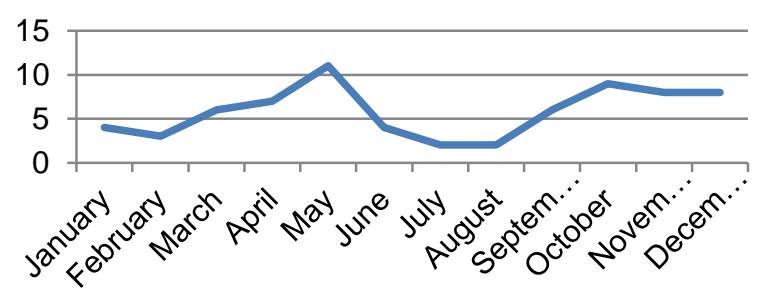

Figure 1 Climate data for Karaisalı for the year 2008 
Fresh and treated wastewater was used as the irrigation water of the study. The fresh water was potable water. Treated wastewater was obtained from a domestic wastewater treatment system of Karaisalı town. This system was constructed as a pilot-scale subsurface vertical flow constructed wetland. Gravel and basaltic tufa were used as media, and Typha latifolia was used as vegetative material in treatment pond. The size of the pond was 5 × 10 meters; and the depth of the pond was 0.5 meters. Some quality parameters of irrigation water according to "Technical Procedures of Notification for Water Pollution Controlling Regulation" published in $7^{\text {th }}$ January 1991 are provided in Table 1. Results revealed fresh water $(\mathrm{FW})$ as the $2^{\text {nd }}$-class and treated wastewater (TWW) as the $3^{\text {rd }}$-class irrigation water.

The experiments were conducted in randomized block design with three replications with 6 plants in each replication. Drip irrigation method was used to irrigate the plants. Lateral spacing in the irrigation system was $50 \mathrm{~cm}$ and dripper spacing was $40 \mathrm{~cm}$. The irrigations were performed once in a week in spring and twice in a week in summer. Irrigation durations were 2 hours in both seasons. The plant growth parameters [plant height $(\mathrm{cm})$, plant diameter $(\mathrm{cm})$, number of shoots, number of live plants] and flowering parameters (number of flowers, flower diameter, flower pedicle thickness, flowering duration) were monitored in a monthly basis. The results were analyzed by SPSS 19.0 statistical software and differences were tested by independent t-test. Finally, assessments were performed and recommendations were provided.

\section{Results and Discussion}

Plant growth parameters of plant height, plant diameter and number of shoots of Tagetes erecta, irrigated with fresh and treated wastewater for seven months are provided in Table 2.

In all growth parameters, the plants irrigated with treated wastewater exhibited better growth during the initial 4 months than the plants irrigated with fresh water. Irrigation water quality did not yield significant differences in plant heights and the highest value (75.44 $\mathrm{cm}$ ) was observed in treated wastewater irrigations in August. However, treated wastewater irrigations resulted in regression in plant growth in September and early die of the plants in October. The tallest plant height (73.38) of fresh water irrigations was also observed in August. The data indicating shorter plant heights for treated wastewater irrigations of the present study comply with the results reported by Grieve et al. (2006) for Matthiola incana and by Carter et al. (2005) for Celosia argentea. Diameters of the plants irrigated with treated wastewater were larger than the diameter of plants irrigated with fresh water during the initial 3 months. The largest diameter $(58.55 \mathrm{~cm})$ was observed in treated wastewater irrigation in July. Except for June $(\mathrm{p}=0.029)$, irrigation water quality did not result in significant differences in plant diameters. There was a distinctive decrease in plant diameter in August. Such a case was because of higher temperatures (average temperature and daily temperature difference) and relative humidity in August and break-off of shoots in treated wastewater-irrigations. With regard to number of shoots, except for the months August, September and October, treated wastewater irrigations yielded higher numbers than that of the fresh water irrigations. Except for June $(p=0.032)$, in which plant growth still continues, irrigation water quality did not result in significant differences in number of shoots. The highest number of shoots (7.61) was observed in plants irrigated with treated wastewater in June. On the other hand, the highest number of shoots (6.87) in fresh water irrigations was observed in October. The present results were similar to the findings of Oliveira-Marinho et al. (2013) indicating the increases in number of shoots of Rosa hybrida 'Ambiance' irrigated with wastewaters with different salinity levels.

Number of living plants was also determined in this study. The plants irrigated with fresh water were all alive for 5 months between May-September, 50\% loss was observed in October and $70 \%$ loss in November. On the other hand, plants irrigated with treated wastewater were all alive during the initial 4 months (May-August); then $15 \%$ loss was observed in September and total die-off was observed in October. Results revealed longer live periods for plants irrigated with fresh water than the plants irrigated with treated wastewater. Since annual landscape plants are not used for long times like 6 months over urban landscapes, treated wastewater irrigations were not considered to have significant negative impacts on $T$. erecta.

Flowering parameters are provided in Table 3. All plants irrigated with treated wastewater exhibited better performance than the plants irrigated with fresh water during the initial 3 months of the experiments.

Irrigation water quality did not result in significant differences in number of flowers (except for the period of October-November since sufficient data were not observed in plants irrigated with treated wastewater). The highest number of flowers (116.66) was observed in June in plants irrigated with treated wastewater. Similarly, highest value in fresh water-irrigations was also observed in June. With regard to flower diameter, irrigation water quality did not result in significant differences only in July. The largest flower diameter $(4.95 \mathrm{~cm})$ was observed in plants irrigated with treated wastewater in May. Flower diameters of treated wastewater-irrigated plants were always higher until August. Later on, flower diameters of fresh water-irrigated plants were higher than those of the plants irrigated with treated wastewater. The largest flower diameter of fresh water-irrigated plants (4.45) was also observed during the initial two months of the flowering. Present data indicated that treated wastewater increased the thickness of flower pedicle during the initial 3 months, but later on had negative impacts of pedicle thickness. These findings comply with the results of Bozdoğan (2013) indicating decreasing trends in $V$. laciniata in Autumn. Irrigation water quality yielded significant differences in flower pedicle thicknesses of all months. The thickest $(3.58 \mathrm{~mm})$ pedicle was observed in plants irrigated with treated wastewater in May. The highest value of fresh water-irrigated plants was also observed in May with $2.77 \mathrm{~mm}$. 
Table 1 Irrigation water characteristics

\begin{tabular}{|c|c|c|c|c|c|c|c|c|c|c|c|}
\hline $\begin{array}{l}\text { Water } \\
\text { type }\end{array}$ & $\mathrm{pH}$ & $\begin{array}{l}\text { Sodium } \\
(\mathrm{meq} / \mathrm{l})\end{array}$ & $\begin{array}{c}\mathrm{EC} \\
\left(25^{\circ} \mathrm{C}\right)\end{array}$ & $\begin{array}{c}\text { Calcium } \\
(\mathrm{meq} / \mathrm{l})\end{array}$ & $\begin{array}{c}\text { Magnesium } \\
(\mathrm{meq} / \mathrm{l})\end{array}$ & $\begin{array}{c}\text { Carbonate } \\
(\mathrm{meq} / \mathrm{l})\end{array}$ & $\begin{array}{c}\text { Bicarbonate } \\
(\mathrm{meq} / \mathrm{l})\end{array}$ & $\begin{array}{c}\text { Chloride } \\
(\mathrm{meq} / \mathrm{l})\end{array}$ & $\begin{array}{c}\text { Sülphate } \\
(\mathrm{meq} / \mathrm{l})\end{array}$ & $\begin{array}{l}\mathrm{Na} \\
(\%)\end{array}$ & SAR \\
\hline FW & 7.2 & 0.96 & 636.1 & 3.81 & 1.58 & 0 & 4.64 & 1.06 & 0.69 & 0.00 & 0.5 \\
\hline TWW & 7.0 & 8.06 & 1471.0 & 4.83 & 1.82 & 0 & 9.84 & 3.17 & 2.26 & 4.88 & 4.4 \\
\hline
\end{tabular}

Table 2 Effects of fresh and treated wastewater irrigations on growth parameters of T.erecta

\begin{tabular}{|c|c|c|c|c|c|c|c|c|}
\hline \multirow{2}{*}{ Parameter } & \multirow{2}{*}{$\begin{array}{l}\text { Irrigation } \\
\text { water }\end{array}$} & \multicolumn{7}{|c|}{ Months } \\
\hline & & May & June & July & August & September & October & November \\
\hline \multirow{3}{*}{$\begin{array}{l}\text { Plant height } \\
(\mathrm{cm})\end{array}$} & FW & 57.66 & 65.22 & 68.27 & 73.38 & 70.94 & 71.25 & 72.71 \\
\hline & TWW & 62.22 & 67.94 & 70.50 & 75.44 & 69.46 & 0.00 & 0.00 \\
\hline & Significance & $0.217^{\text {n.s. }}$ & $0.506^{\text {n.s. }}$ & $0.571^{\text {n.s. }}$ & $0.606^{\text {n.s. }}$ & $0.774^{\text {n.s. }}$ & $0.000^{*}$ & $0.000^{*}$ \\
\hline \multirow{3}{*}{$\begin{array}{l}\text { Plant diameter } \\
(\mathrm{cm})\end{array}$} & FW & 36.50 & 41.22 & 47.55 & 36.16 & 37.50 & 52.00 & 62.42 \\
\hline & TWW & 40.61 & 52.66 & 58.55 & 27.16 & 42.33 & 0.00 & 0.0 \\
\hline & Significance & $0.324^{\text {n.s. }}$ & $0.029^{* *}$ & $0.071^{\text {n.s. }}$ & $0.304^{\text {n.s. }}$ & $0.540^{\text {n.s. }}$ & $0.000^{*}$ & $0.001^{*}$ \\
\hline \multirow{3}{*}{$\begin{array}{l}\text { Number of } \\
\text { Shoots }\end{array}$} & FW & 5.16 & 6.50 & 4.83 & 3.88 & 5.50 & 6.87 & 6.85 \\
\hline & TWW & 5.50 & 7.61 & 7.11 & 3.77 & 5.93 & 0.00 & 0.00 \\
\hline & Significance & $0.614^{\text {n.s. }}$ & $0.249^{\text {n.s. }}$ & $0.032^{* *}$ & $0.923^{\text {n.s. }}$ & $0.660^{\text {n.s. }}$ & $0.002^{* *}$ & $0.004^{*}$ \\
\hline
\end{tabular}

n.s.: not-significant; $* \mathrm{p}<0.001 ; * * \mathrm{p}<0.01$

Table 3 Effects of fresh and treated wastewater irrigations on flowering parameters of T.erecta

\begin{tabular}{l|lccccccc}
\hline \multirow{2}{*}{ Parameter } & Irrigation & \multicolumn{7}{c}{ Months } \\
\cline { 2 - 8 } & Water & May & June & July & August & September & October & November \\
\hline \multirow{3}{*}{ Number of flower } & FW & 41.00 & 92.66 & 77.33 & 70.33 & 28.66 & 16.66 & 37.33 \\
& TWW & 49.33 & 116.66 & 83.33 & 54.00 & 6.66 & 0.00 & 0.00 \\
& Significance & $0.507^{\text {n.s. }}$ & $0.446^{\text {n.s. }}$ & $0.853^{\text {n.s. }}$ & $0.481^{\text {n.s. }}$ & $0.067^{\text {n.s. }}$ & $0.007^{* *}$ & $0.014^{* *}$ \\
Flower diameter & FW & 4.45 & 4.45 & 3.87 & 3.79 & 3.47 & 3.46 & 3.71 \\
(cm) & TWW & 4.95 & 4.79 & 3.95 & 3.35 & 2.05 & 0.00 & 0.00 \\
& Significance & $0.024^{* *}$ & $0.046^{* *}$ & $0.580^{\text {n.s. }}$ & $0.016^{* *}$ & $0.004^{* *}$ & $0.000^{*}$ & $0.000^{*}$ \\
Flower pedicle & FW & 2.77 & 1.84 & 2.15 & 2.59 & 2.32 & 1.78 & 2.14 \\
thickness (mm) & TWW & 3.58 & 2.97 & 2.79 & 2.26 & 1.33 & 0.00 & 0.00 \\
& Significance & $0.000^{*}$ & $0.000^{*}$ & $0.000^{*}$ & $0.090^{* *}$ & $0.002^{* *}$ & $0.000^{*}$ & $0.000^{*}$ \\
\hline
\end{tabular}

n.s.: not-significant; $* \mathrm{p}<0.001 ; * * \mathrm{p}<0.05$

In addition to flowering parameters, flowering durations were also assessed in this study. Results revealed that flowering periods of the plants irrigated with fresh water (210 days) were longer than the flowering periods of the plants irrigated with treated wastewater (150 days). These findings comply with the results of Bozdoğan (2013) reporting negative impacts of treated wastewater irrigations on flowering of $V$. laciniata during the first year.

\section{Conclusion}

Marigold (Tagetes erecta) is a seasonal flower and commonly preferred in Mediterranean Region because of long-lasting flowering. Following conclusions were drawn from this study investigating the effects of clean water and treated wastewater irrigation on growth and flowering parameters of marigold: Treated wastewater irrigations did not result in negative impacts on growth and flowering parameters of $T$. erecta during the initial three months (May, June and July). Contrarily, the plants irrigated with treated wastewater had higher plant heights, plant diameters, number of shoots, number of flowers, flower diameters and flower pedicle diameters than the plants irrigated with fresh water during these initial three months. However, treated wastewater irrigations decreased the flowering durations. Considering the number of live plants, shorter lives of plants irrigated with treated wastewater were not considered as a problem for seasonal flowers. Therefore, it was concluded that treated wastewaters could be used as an alternative source in irrigation of $T$. erecta to provide a support to clean potable waters. However, long-term use is not recommended and/or mixture with fresh water at various ratios is recommended.

\section{References}

Andreadakis A, Gavalaki E, Mamais D, Tzimas A. 2001. Wastewater Reuse Criteria in Greece. 7th Conference on Environmental Science and Technology, 3 -6 September 2001, Ermoupolis, Syros Island, Greece. Global Nest: the Int. J. Vol 5, No 1: 9-14.

Bakopoulou S, Emmanouil C, Kungolos A. 2011. Assessment of wastewater effluent quality in Thessaly region, Greece, for determining its irrigation reuse potential. Ecotoxicology and Environmental Safety, 74: 188-194.

Balman AH, Balman V. 2002. Çevre Kirliliği Kontrolünde Atıksu Arıtımı. "Wastewater Treatment for Pollution Control" İkinci Baskıdan Türkçeye Çeviri, Atılım Ofset, Ankara, $473 \mathrm{~s}$.

Banon S, Miralles J, Ochoa J, Franco JA, Sanchez-Blanco MJ. 2011. Effects of Diluted and Undiluted Wastewater on the Growth, Physiological Aspects and Visual Quality of Potted Lantana and Polygala Plants. Scientia Horticulturae, 129 (4): 869-876.

Bozdoğan E. 2009. Kentsel Atık Suların Yapay Sulak Alanda Arıtılması ve Açık Yeşil Alan Sulamalarında Kullanılabilme Olanaklarının Araştırılması. Ç.Ü. Fen Bilimleri Enstitüsü, Peyzaj Mimarlı̆̆ 1 Anabilim Dalı, Doktora Tezi, Adana, 232 S.

Bozdoğan E, Söğüt Z, Çetinkale G, Erzurumlu G.S. 2010. Bazı Çim Türlerinin Çimlenmesinde ve Gelişimininde Arıtılmış Atık Suyun Yeniden Kullanımı. IV. Süs Bitkileri Kongresi, 20-22 Ekim 2010, Bildiriler Kitabı: 302-311. 
Bozdoğan E. 2013. Arıtılmış Atık Su İle Sulamanın Çok Yıllık Otsu Verbena laciniata Türünün Büyümesi Üzerine Etkisi. V. Süs Bitkileri Kongresi, 06-09 Mayıs 2013, Yalova.

Braatz S, Kandiah A. 2005. The Use of Municipial Wastewater for Forest and Tree Irrigation. FAO Corporate Document Repository.

Brenner A, Shandalov S, Messalem R, Yakırevich A, Oron G, Rebhun M. 2000. Wastewater reclamation for agricultural reuse in Israel: Trends and experimental results. Water, Air, and Soil Pollution, 123: 167-182.

Carter CT, Grieve CM, Poss JA, Suarez DL. 2005. Production and Ion Uptake of Celosia argentea Irrigated with Saline Wastewaters. Scientia Horticulture, 106 (3): 381-394.

Carter CT, Grieve CM. 2008. Mineral nutrition, growth, and germination of Antirrhinum majus L. (snapdragon) when produced under increasingly saline conditions. HortScience, 48 (3): 710-718.

Cassaniti C, Romano D, Hop MECM, Flowers TJ. 2013. Growing floricultural crops with brakish water. Environmental and Experimental Botany, 92: 165-175

Cazurra T. 2008. Water Reuse of South Barcelona's Wastewater Reclamation Plant. Desalination, 218: 43-51.

Chang D, Ma Z. 2012. Wastewater reclamation and reuse in Being: Influence factors and policy implications. Desalination, 297: 72-78.

DSİ. 2012. Toprak su kaynakları. www.dsi.gov.tr

Ebcioğlu N. 2009. Bahçe Çiçekleri. Türkiye İş Bankası Kültür Yayınları, İstanbul, $318 \mathrm{~s}$.

EC. 2012. Science for Environment Policy. DG Environment News Alert Service. European Commision. http://ec.europa.eu/environment/integration/research/newsal ert/future_briefs.htm

EPA. 2004. Guidelines for Water Reuse. United States Environmental Protection Agency, EPA/625/R-04/108, Washington, DC.

FDEP. 2002. 2001 Reuse Inventory. Florida Department of Environmental http://www.dep.state.fl.us/water/reuse/

Gerhart VJ, Kaneb R, Glenn EP. 2006. Recycling Industrial Saline Wastewater for Landscape Irrigation in a Desert Urban Area. Journal of Arid Environments, 67: 473-486.

Gori R, Ferrini F, Nicese FP, Lubello C. 2000. Effect of Reclaimed Wastewater on the Growth and Nutrient Content of Three Landscape Shrubs. J. Environ. Horticulture, 18(2):108-114.

Grieve CM, Poss JA, Amrhein C. 2006. Response of Matthiola incana to irrigation with saline wastewaters. HortScience, 41(1): 119-123
Hochstrat R, Joksimovic D, Wintgens T, Melin T, Savic D. 2007. Economic consideration and decisions support tool for wastewater reuse scheme planning. Water Sci. Tecknology, 56 (5): $175-182$

IRC. 2005. Wastewater Reuse in Latin America: Quality Issues Need Attention. http://www.irc.nl/page/26895

Lazarova V. 1999. Wastewater Reuse: Technical Challenges and Role in Enhancement of Integrated Water Manegement. G.I.N. International, Dec. 99: 40-47.

Levine AD, Asano T. 2004. Recovering sustainable water from wastewater. Environmental Science and Technology, June 1: 201-208.

Lubello C, Gori G, Nicese FP, Ferrini F. 2004. MunicipialTreated Wastewater Reuse for Plant Nurseries Irrigation. Water Research, 38: 2939-2947.

Meneses M, Pasqualino JC, Castells F. 2010. Environmental assessment of urban wastewater reuse: Treatment alternatives and applications. Chemosphere, 81: 266-272.

Niu G, Cabrera RI. 2010. Growth and phsyiological responses of landscape plants tos aline water irrigation: a review. HortScience, 45 (11): 1605-1609.

Oliveira-Marinho LE, Tonetti, AL, Stefanutti R, Filho BC. 2013. Application of reclaimed wastewater in the irrigation of rosebushes. Water Air Soil Pollution, 224: 1669-1676.

Orçun E. 1972. Süs Bitkileri (İlkbahar ve Yaz Çiçekleri). Ege Üniv. Ziraat Fakültesi Yayınları No: 142, EÜ Matbaas1, İzmir, $173 \mathrm{~s}$.

Paulo PL, Azevedo C, Begosso L, Galbiati AF, Boncz MA. 2013. Natural systems treating greywater and blackwater onsite: Integrating treatment, reuse and landscaping. Ecological Engineering, 50: 95-100.

Sakellariou-Makrantonaki M, Tentas I, Koliu A, Kalfountzos D, Vyrlas P. 2003. Irrigation of Ornamental Shrubs with Treated Municipial Wastewater. Proceedings of the $8^{\text {th }}$ International Conference on Environmental Science and Technology. 8-10 September 2003, Lemnos Island, Greece, Vol B: 707-714.

SFWMD. 2002. South Florida Water Management District. Water Reuse: A Safe and Effective Way to Save Water, Florida.

Shetty S. 2005. Treated Wastewater Use in Tunisia: Lessons Learned and The Road Ahead. http://www.idrc.ca/en/ev68343-201-1-DO_TOPIC.html

Qian Y. 2006. Urban Landscape Irrigation With Recycled Wastewater. Completion Report No: 204, Colorado Agricultural Experiment Station Project Number: 658, USA. Yücel E. 2012. Çiçekler ve Yerörtücüler. Eskişehir, 351 s. 